\title{
Selectivity of Ethyl Acetate Fraction of Gynura Procumbens on Colon Cancer and Breast Cancer
}

\author{
Nunuk Aries Nurulita ${ }^{1,2}$, Edy Meiyanto ${ }^{3}$, Sugiyanto $^{3,4}$ \\ ${ }^{1}$ Faculty of Pharmacy, Universitas Muhammadiyah Purwokerto, Jawa Tengah, \\ ${ }^{2}$ Graduate Program of Pharmaceutical Sciences, Faculty of Pharmacy, Universitas Gadjah Mada, Yogyakarta, \\ ${ }^{3}$ Cancer Chemoprevention Research Center, Faculty of Pharmacy, Universitas Gadjah Mada, Yogyakarta \\ ${ }^{4}$ Department of Pharmacology and Clinical Pharmacy, Faculty of Pharmacy, Universitas Gadjah Mada, Yogyakarta
}

\begin{abstract}
Gynura procumbens is widely used as traditional remedy in South-East Asia. Gynura procumbens exhibites anti inflammatory, antioxidant, and reduced blood pressure activity. The aim of this study was to determine chromatographic profile of ethyl acetate fraction of Gynura procumbens (FEG) and to investigate its cytotoxic properties and selectivity to colon cancerand breast cancer cancer cells. The chromatographic profile of FEG was determined using HPTLC densitometric and HPLC. MTT (3-(4,5-dimethyl-thiazol-2-yl)-2,5-diphenyltetrazolium bromide) assay was performed to determine the growth inhibitory effect of FEG on the growth of WiDr, MCF-7, and T47D cells. NIH3T3, a normal cells was used to determine the selectivity of FEG, which contained small amount of quercetin as identified from chromatographic profile both HPTLC and HPLC. FEG inhibited cell growth of WiDr, of MCF-7 and of T47D cells in time dependent manner. Quercetin affected cell growth inhibition approximately two fold higher at WiDr and MCF-7, whereas FEG had lower effect on T47D cell. Quercetin did not seem as the main active compound of FEG. At this study, FEG caused less inhibition on the growth of $\mathrm{NIH} 3 \mathrm{~T} 3$ cells than that of on all cell lines. Selectivity index (SI) of FEG on WiDr, MCF-7 and T47D were 4.97, 2.77 and 7.79 respectively. According to the datas obtained, FEG possesses moderate to high cytotoxicity properties on WiDr, MCF-7 and T47D cells. FEG demonstrates selective effect against cancer cells and reveals prospective properties as cancer chemoprevention agent.
\end{abstract}

Keywords: Gynura procumbens, colon cancer, breast cancer, cytotoxicity, selectivity

\section{INTRODUCTION}

Breast cancer and colon cancer are the two of the most five deadly cancer diseases together with lung cancer, stomach cancer and hepatocarcinoma. Approximately 1,2 million cases of colorectal cancer are expected to occur in 2007. While 1,3 million new cases of invasive breast cancer are expected in 2007 (Garcia et al., 2007). Breast cancer caused 519.000 death per year, while colon cancer causes 639.000 patient death per year (WHO, 2006). In Indonesia, breast cancer prevalence is the second range after cervix cancer and become the major caused on women mortality.

Combination therapy using surgery, chemotherapy and radotherapy resulted dissatisfied achievement. Many cancer chemotherapeutic drugs present relatively poor selectivity for neoplastic cells. The failure of cancer chemotherapy partly is resulted from the low selectivity of anticancer drugs and the unclear of molecular target on cancer. Drugs with low selectivity affect several side effect on patient. Research efforts have been carried on to overcome these problems by developing more effective and selective anticancer drugs through consideration of the molecular target and mechanisms. Plant bioactive compounds are normally cheaper and produce lower side effects respected to chemotherapy.

Thus, the searching for active compounds extracted from plant is an important path of research in the discovery of novel anticancer candidates. Gynura procumbens (G. procumbens) is a medicinal plant with several biological activity related with anticancer. G. procumbens extract and its fractions exhibit high antioxidant properties shown by xantine oxidase inhibition and radical scavenging activity.

\footnotetext{
*Corresponding author e-mail:nunuknurulita@yahoo.com
} 
The uncontrolled production of radical oxygen species (ROS) and unbalance antioxidant protective system have an important part on cancer initiation and development (Rosidah et al., 2008). These natural antioxidants may become a beneficial agent to be developed as chemoprevention substance for cancer disease. $G$. procumbens inhibited carcinogenesis process of lung cancer (Sugiyanto et al., 2003) and breast cancer (Meiyanto et al., 2007a; Meiyanto et al., 2007b) and has antimutagenic properties on benzo(a)pyrene-induced mice lung cancer (Meiyanto, 1996). The phenolic compounds of $G$. procumbens suppressed cells proliferation and induced apoptosis at $\mathrm{HeLa}$ (Meiyanto dan Septisetyani, 2005), and T74D cells (Maryati, 2006), and also has antiangiogenic properties (Jenie et al., 2007). Phenolic compounds of $G$. procumbens decreased Cox-2 expression (in vivo) and elevated $p 53$ and Bax expression (in vitro) (Maryati et al., 2006).

To our knowledge, no specific study had been reported addressing the selective cytotoxic effects of FEG on colon cancer WiDr and breast cancer MCF-7 and T47D and normal NIH3T3 cell lines. Thus, in this present study, we have evaluated the in vitro cytoxicity of FEG on those cells. Results from both cancerous and normal cell were then compared to determine the selective activity.

\section{MATERIALS AND METHODS}

\section{Chemicals and Reagents}

Material were used in this study: DMEM (Nacalay, Japan), Fetal Bovine Serum (FBS) (PAA), Dimethyl sulfoxide (DMSO) (Sigma, Aldrich, Germany), penicillin and streptomycin (Gibco), tripsin (Sigma), 3-(4,5-dimethyltiazol-2il)-2,5-diphenyltetrazolium bromide (MTT), sodium dodecyl sulphate (SDS). Tris- $\mathrm{HCl}$, ethanol, n-hexane, and ethyl acetate and fraction of ethyl acetate $G$. procumbens (FEG). The fractions was dissolved in DMSO with $0,1 \%$ as maximum concentration. All of the chemicals were on the higher degree of quality.

\section{Human cell lines}

Human colon cancer cell WiDr and breast cancer cell MCF-7 and T47D was provided from Cancer Chemoprevention Research Centre (CCRC) collection. NIH3T3 cell was kindly provided from Prof. Masashi Kawaichi, Laboratorium of Gene Function in Animal, Nara Institute of Science and Technology. WiDr cells were cultured in Rosewell Park Memorial Institute
(RPMI) containing $10 \%$ heat-inactivated fetal bovine serum (FBS) $1 \%$ Penicillin-streptomycin $(\mathrm{v} / \mathrm{v})$, and L-glutamine $(1 \mathrm{mM})$ at $37^{\circ} \mathrm{C}$ and $5 \%$ CO2. MCF-7 and T47D cells were routinely grown in Dulbecco's modified eagle's medium (DMEM) and added the same supplement as that to RPMI medium. NIH3T3 cells were routinely grown in DMEM supplemented with 10\% heatinactivated fetal calf serum (FCS) (PAA Labortories), $1 \%$ Penicillin-streptomycin (v/v), and L-glutamine $(1 \mathrm{mM})$ at $37^{\circ} \mathrm{C}$ and $5 \% \mathrm{CO} 2$.

\section{Plant material}

The leaves of G. Procumbens were obtained from the collection of Balai Penelitian dan Pengembangan Tanaman Obat dan Obat Tradisional (BP2TO2T) Indonesia, and was determined at Laboratorium of Pharmacognocy, Faculty of Pharmacy Gadjah Mada University, Indonesia. Dry powder of Gynura procumbent was re-macerated with $96 \%$ ethanol for three time with three days maceration for each process. All filtrate then evaporated using rotary evaporator until a thick liquid extract was obtained. The ethanolic extract was dissolved in hot aquadest then fractionated using $\mathrm{n}$-hexane. The water fraction then continued to fractionate with ethyl acetate. The ethyl acetate fraction was evaporated using rotary evaporator. The ethyl acetate extract was concentrated by evaporation under reduced pressure and the temperature was kept not more than $40^{\circ} \mathrm{C}$. The extract was stored at $4^{\circ} \mathrm{C}$ prior to use.

\section{Determination of chromatographic profile of FEG}

Chromatography profile of FEG was determined using high performance thin layer chromatography (HPTLC) dan high performance liquid chromatography (HPLC). Mobile phase that used for HPTLC was toluene:chloroform:aceton:acetic acid (4:4:4:1) and using silica gel $60 \mathrm{~F}_{254}$ (Merck) as stationary phase. Ultraviolet (UV) detection at $254 \mathrm{~nm}$ in wave length was used for spot visualization. The all spots were scanned using TLC Scanner (CAMAG), deuterium and wolfram $\left(\mathrm{D}_{2} \& \mathrm{~W}\right)$ lamp, at $380 \mathrm{~nm}$. Coloumn silica Symmetry C18 (lenght $\mathrm{x}$ internal diameter: $150 \mathrm{~mm} \times 4.6 \mathrm{~mm}$, particle size $15 \mathrm{~mm}$ ) was used as stationery phase for HPLC. The mobile phase was acetonitrile: formic acid (25:75). The eluent was detected by ultraviolet-visible (UV-VIS) detector at 360 visualization of the spot. Quercetin (QUER) (Sigma-Aldrich, $\geq 98 \%$ HPLC, CAS No. 117-395)) and kaempferol (KAEMP) (Sigma-Aldrich, 
$\geq 90 \%$ HPLC, CAS No. 520-18-3) were used as marker.

\section{Cytotoxicity assessments}

Cells $\left(10^{4}\right.$ cells/well $)$ were cultured at 96 well plate. After 24 hours growth, cells culture medium was replaced with 5-FU, CISP, and/or FEG-contained medium. After incubated for 24 hours, the medium was replaced with MTTcontaining medium $(0,5 \mathrm{mg} / \mathrm{mL})$ and incubated for 4 hours at $37^{\circ} \mathrm{C}, 5 \% \mathrm{CO}_{2}$. The reaction was stopped with $10 \%$ SDS in $0,1 \mathrm{~N} \mathrm{HCl}$ solution and was incubated for overnight in light protected chamber, to dissolve formasan salt. The absorbance of each well was measured with ELISA reader at $595 \mathrm{~nm}$. The ratio between treated and control cells absorbance refer to percentage (\%) of viable cells.

\section{Selectivity index (SI)}

In the present study, the degree of selectivity of FEG refered to the previous report (Badisa et al., 2006), was calculated using formula: SI=LC50 in normal cells /LC50 in cancer cell lines, where LC50 is the concentration required to kill $50 \%$ of the cell population.

\section{RESULTS AND DISCUSSION}

\section{Chromatography profile of ethyl acetate fraction of Gynura procumbens}

Ethyl acetate fraction of Gynura procumbens was fractionated twice separately, produced two different batch of ethyl acetate fraction (FEG). This FEG was obtained from liquid-liquid fractionation of ethanolic extract using n-heksane-hot water and continued with ethyl acetate-water. From the two fractionations were obtained percentage of FEG $1,6 \%$ and 1,7 $\%$, respectively. FEG was analized its chromatographic profile using High Performance Thin Layer Chromatography (HPTLC) and High Performance Liquid Chromatography (HPLC) as shown on Fig. 1 and 2 respectively. Quercetin (QUER) and kaempferol (KAEMP) were used as marker compound. Both FEG from different batch had similar chromatographic profile as result of HPTLC and HPLC. Most of chromatogram refered to flavonoid compound. From the scanning of maksimum wave lenght we concluded FEG may contained quercetin, but not kaempferol. However the amount of quercetin was not dominated the active compound of FEG.

\section{Inhibitory effect of FEG on WiDr, MCF-7 and T47D cells growth}

To determine the potency of FEG as anticancer agent, first the cytotoxicity properties were examined in WiDr colon cancer cell, MCF-7 and T47D breast cancer cells. Cell viability was examined using MTT assay method after 24 hours incubation. FEG caused cell growth inhibition on WiDr, MCF-7 and T47D cells in dose dependent manner with $\mathrm{IC}_{50}$ value $119 \mu \mathrm{g} / \mathrm{mL}, 214 \mu \mathrm{g} / \mathrm{mL}$ and $76 \mu \mathrm{g} / \mathrm{mL}$, respectively (Table I). FEG had moderate to high potency as cytotoxic agent. The highest potency was shown on T47D cell. Quercetin also caused cell growth inhibition on three cells in dose dependent manner with $\mathrm{IC}_{50}$ value $56 \mu \mathrm{g} / \mathrm{mL}, \quad 169 \mu \mathrm{g} / \mathrm{mL}, \quad 127 \mu \mathrm{g} / \mathrm{mL}$, respectively. These results demonstrated that quercetin was not the main active compound of FEG.

\section{FEG shows lower cell growth inhibition in normal cells than that of cancer cells}

Cytotoxicity results showed moderate to high potency of FEG to be developed as anticancer agent. In order to determine the selectivity of FEG, we performed cytotoxic properties of FEG on normal cells, NIH3T3 (Fig.3). FEG gave no significant effect up to $400 \mu \mathrm{g} / \mathrm{mL}$ on NIH3T3 cell growth after 24 hours incubation. While after 72 hours, FEG caused cell growth inhibition at minimal concentration $600 \mu \mathrm{g} / \mathrm{mL}$. $\mathrm{IC}_{50}$ value of FEG was measured after 24 and 72 hours of FEG treatment, resulted $592 \mu \mathrm{g} / \mathrm{mL}$ and $538 \mu \mathrm{g} / \mathrm{mL}$, respectively. FEG shows lower cell growth inhibition in NIH3T3 than that in WiDr, MCF-7 and T47D cells. FEG shows lower inhibition on the growth of normal cells than that of cancer cell. 

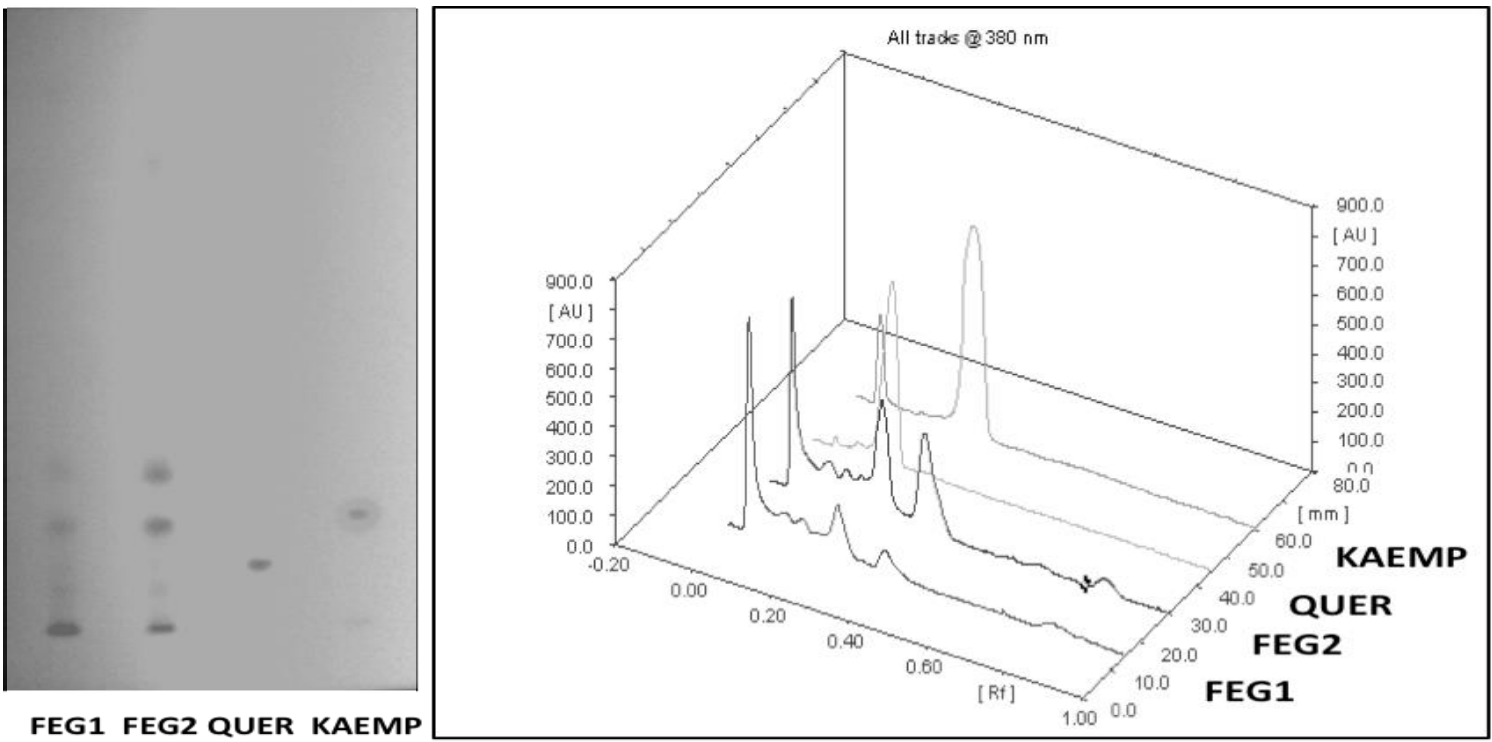

Figure I. Chromatogram profile of FEG was compared with Quercetin (QUER) and Kaempferol (KAEMP) as marker using HPTLC. FEG, QUER and KAEMP wre analized using HPTLC with silica gel 60 F254 as stationary phase and toluene:kloroform:aseton:asam asetat (4:4:4:1) as mobile phase (Lalla et al., 2003). Silica plate was visualized under UV light $254 \mathrm{~nm}$ then scanned using densitometer, $380 \mathrm{~nm}$.

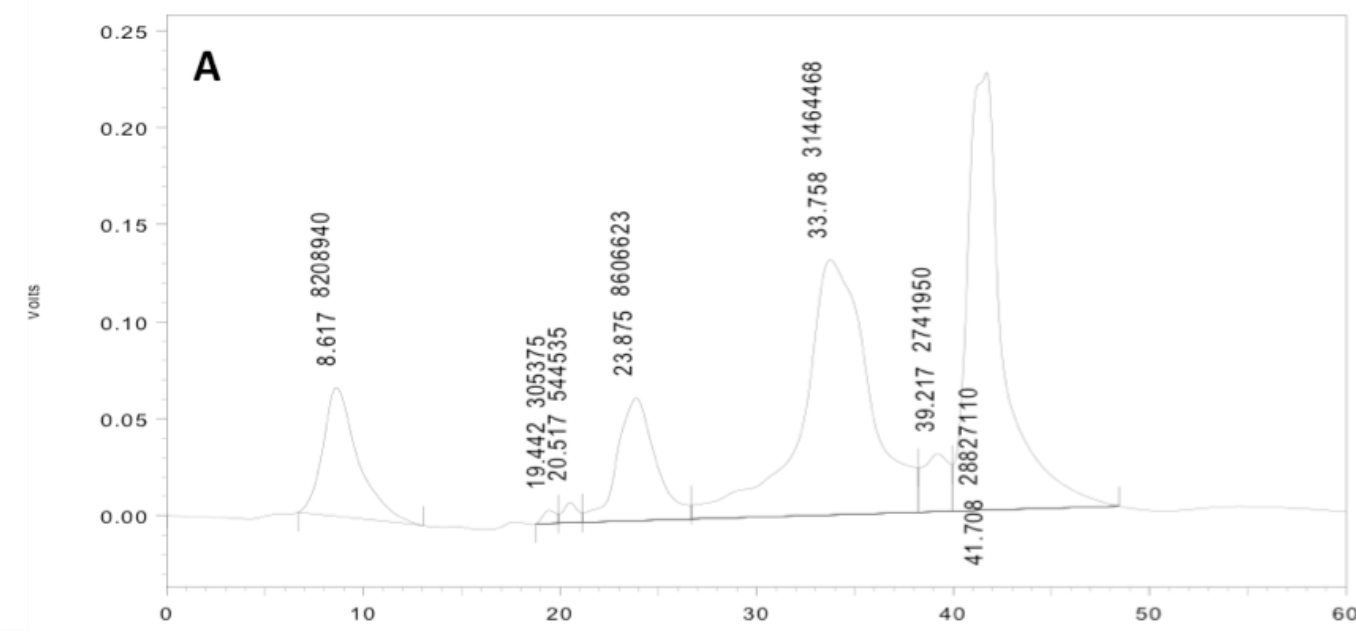

B

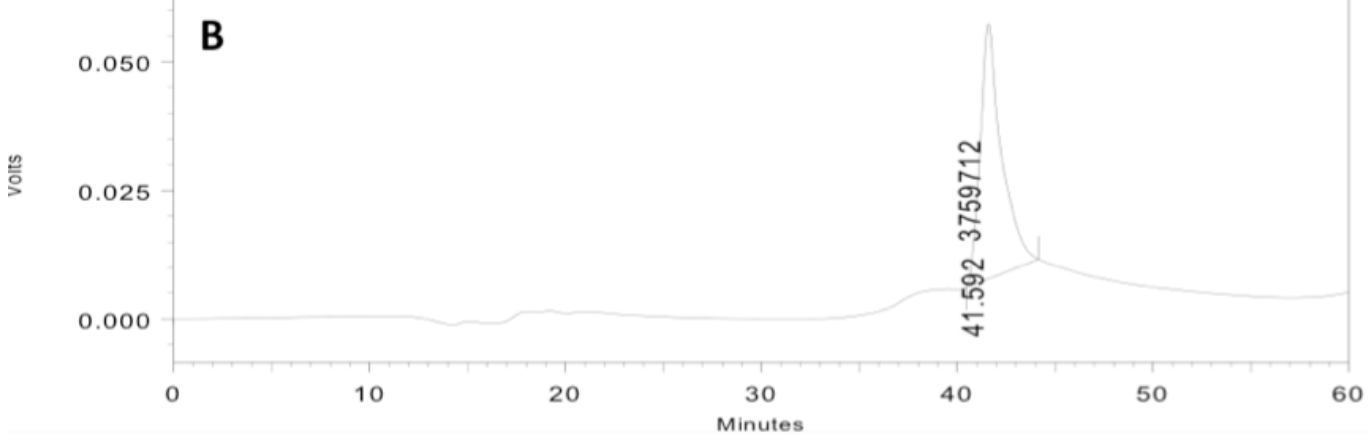

Figure 2. Chromatogram profile of FEG-contained compounds using HPLC. Chromatogram profile of FEGI (A), FEG2 (B), and QUER (C). FEG and QUER were diluted in ethyl acetate with the indicated concentrations as described at method. FEG and quercetin solution was analyzed using HPC with Asetonitril: asam formiat (25:75) as mobile phase and silica coloumn symmetry Cl8, detector UV-VIS. 

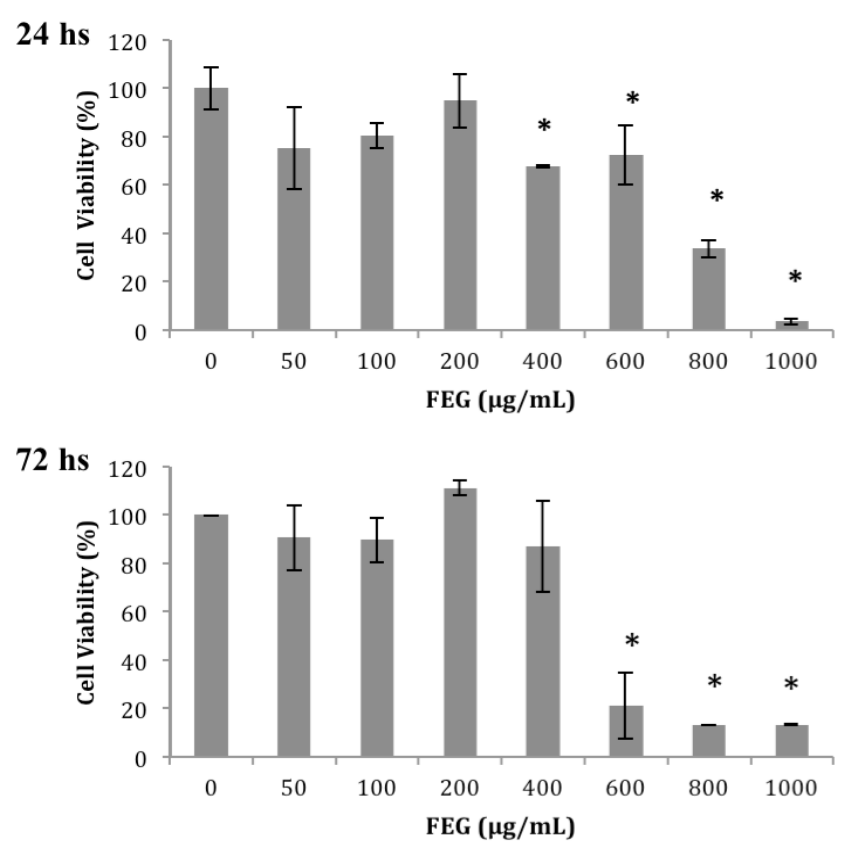

Figure 3. The effect of FEG on NIH3T3 cells growth. FEG treatment up to $400 \mu \mathrm{g} / \mathrm{mL}$ caused no significant cell growth inhibition. Cells ( $10^{4}$ cells/well) were seeded at 96 -well plate. After 24 hours growed, cells were treated with FEG $(0-1000 \mu \mathrm{g} / \mathrm{mL})$ for 24 and 72 hours. Cells viability were determined using MTT assay. T Test analysis, with $95 \%$ confidency was used to conclude the significance of cells growth inhibition. *FEG inhibit cell growt significantly $(p>0,05)$.

Table I. IC50 Value of FEG and QUER on WiDr, MCF-7 and T47D cells and The selectivity index (SI) which represents IC50 of FEG for normal cell line/IC50 for cancerous cell line after 24 hours incubation

\begin{tabular}{|c|c|c|c|}
\hline Cells & Sample & $I^{\prime} C_{50}$ Value* & $\begin{array}{l}\text { Selectivity Index } \\
\text { (SI) }\end{array}$ \\
\hline WiDr & $\begin{array}{l}\text { FEG } \\
\text { QUER }\end{array}$ & $\begin{array}{ll}119 & \mu \mathrm{g} / \mathrm{mL} \\
56 & \mu \mathrm{g} / \mathrm{mL}\end{array}$ & 4.97 \\
\hline MCF-7 & $\begin{array}{l}\text { FEG } \\
\text { QUER }\end{array}$ & $\begin{array}{ll}214 & \mu g / m L \\
169 & \mu g / m L\end{array}$ & 2.77 \\
\hline T47D & $\begin{array}{l}\text { FEG } \\
\text { QUER }\end{array}$ & $\begin{array}{ll}76 & \mu \mathrm{g} / \mathrm{mL} \\
127 & \mu \mathrm{g} / \mathrm{mL}\end{array}$ & 7.79 \\
\hline
\end{tabular}

*represented from al least 2 (two) independent experiments.

Many researchers are now interested in examining the use of herbal medicines as a health care method. Herbal medicines continue to be accepted forms of treatment in the Orient, and the plant derived drugs based on traditional practices represent a huge proportion of the pharmaceutical production in modern Western countries (Newall et al., 1996 Schulz et al., 1998). Development of biologically targeted agents that exploit differences between cancerous and normal cells and permit greater specificity for cancer cells with less damage to normal cells is still the ultimate goal in the field of antineoplastic drug discovery (Adam, 2001). Until now, no ideal cytotoxicity assay has been developed; hence, it is always advisable to support results with more assays where possible. Besides, it is important that of compare the cytotoxicity of a novel compound against several cell lines and even with other commercial cytotoxic agents. In this study, we showed the profile of bioactive compounds of ethyl acetate fraction of $G$. procumbens (FEG). We also confirmed the cytotoxicity properties of FEG and its selectivity directed human colon cancer and breast cancer cells.

HPTLC analysis of FEG shown three main spots, similar with previous results from study of Sugiyanto et al., (2003). Previous study showed 3 (three) main spots that had been identified as flavon/flavonol. The first flavonoid was identified as flavonol derivate with $5-\mathrm{OH}$ and $3,7-\mathrm{OCH}_{3}$. He second flavonoid was flavonol derivate with 5,7 - OH and 3-Oglucosil. The third flavonoid was similar with the second flavonoid. Flavonol 
derivative that has 7 -alkoksi, $3^{\prime}$ and 4' di-OH, and 3,5 di-OH (Sugiyanto et al., 2003). The third flavonoid was quercetin derivative with alkoksi substitution on $7-\mathrm{OH}$. Previous results also found quercetin, kaempferol and its derivate in $G$. procumbens (Akowuah et al., 2002). Methanolic extract may contain kaempferol-3-O-rutinosida dan astragalin (Rosidah et al., 2009), and its ethanolic extract has been identified as kaempferol-3-O-rutinosida, quercetin-3-Orutinosida, dan isobioquercetin compounds (Kim et al., 2011). HPLC results of FEG showed chromatogram peak with retention time (tR) value of 41.7 similar to the $\mathrm{tR}$ value of quercetin 41.6. Therefore FEG may contain quercetin. However there are others compound also contained in the chromatogram peak.

FEG shows moderate to high cytotoxicity properties on colon cancer and breast cancer as indicated on the $\mathrm{IC}_{50}$ value at WiDr, MCF-7 and T47D cells. While quercetin presented higher potency (almost 3 fold) on cytotoxicity compared to FEG on WiDr and MCF-7 cells. Conversely quercetin demonstrated lower potency on cytotoxic properties on T47D cells. This phenomenon may cause by different cells characteristic or different target of action. The results of cytotoxicity assay showed that quercetin does not seem as the main active compound of FEG. There are other compounds contained in FEG that have pivotal portion on its cytotoxicity properties.

Since FEG had high potency of cytotoxicity, its impotant to reveal the selectivity of this fraction. FEG produced no significance effect on cell growth inhibition up to $400 \mu \mathrm{g} / \mathrm{mL}$ concentration at NIH3T3 cells. Selectivity of FEG on WiDr and T47D cells higher than that on T47D. FEG exhibited very high selectivity on WiDr and MCF-7 cells as shown by selectivity index (SI), that is > 3. Even as on MCF-7, FEG demonstated moderate selectivity properties.

\section{CONCLUSION}

The present in vitro studies FEG possesses moderate to high cytotoxicity properties on WiDr, MCF-7 and T47D cells. FEG shows selective effect against cancer cells. Further FEG reveals prospective properties to be developed as cancer chemoprevention agent.

\section{ACKNOWLEDGEMENT}

This work was supported in part by Research Grants of Hibah Doktor and Hibah Bersaing, managed by the Directorate General of
Higher Education Republic of Indonesia, 2010/2011.

\section{REFERENCES}

Adams, J., 200I, Proteasome inhibition in cancer: Development of PS-34I, Sem. Oncol., 28, 613-619.

Akowuah, G.A., Sadikun, A. and Mariam, A., 2002. Flavonoid identification and hypoglycaemic studies of butanol fraction from Gynura procumbens, Pharmaceut. Biol., 40, 405-4I0.

Badisa, R.B. and Lambert, A.T., 2006, Ikediobi CO and Walker EH: Selective anticancer activity of pure licamichauxiioic-B acid in culture cell lines, Pharmaceut Biol., 44(2), $|4|-\mid 45$.

Garcia, M., Jemal, A., Ward, E.M., Center, M.M., Hao, Y., Siegel, R.L. and Thun, M.J., 2007, Global Cancer Facts \& Figures 2007, Atlanta, GA: American Cancer Society.

Jenie, R.I., Meiyanto, E. and Murwanti, R., 2006, Antiangiogenic effect of sambung nyawa leaves (Gynura procumbens (Lour.) Merr.) etanolic extract on chick embryo chorioallantoic membrane (CAM), Indonesian Journal of Pharmacy, I7(I), 50-55.

Kim, J., Lee, C.W., Kim, E.K., Lee, S.J., Park, N.H., Kim, H.S., Kim, H.K., Char, K., Jang, Y.P. and Kim, J.W., 20II, Inhibition effect of Gynura procumbens extract on UV-Binduced matrix-metalloproteinase expression in human dermal fibroblast, $J$. Ethnopharmacol., I37(I), 427-433.

Maryati, Meiyanto, E. and Riyanto, S., 2005, Uji Sitotoksik dan isolasi flavonoid dari fraksi etil asetat daun Gynura procumbens (Lour) Merr, Pharmacon., 6(2), 46-50.

Meiyanto, E. and Septisetyani, E.P., 2005, Antiproliferative and apoptotic effect of fenolic fraction of ethanolic extract of Gynura procumbens (Lour.) Merr. Against HeLa Cells, Artocarpus., 5(2), 74-80.

Meiyanto, E., Susilowati, S., Tasminatun, S., Murwanti, R., and Sugiyanto, 2007, Chemopreventive effect of ethanolic extract of Gynura procumbens (Lour), Merr on the carcinogenesis of Rat breast cancer development, Indonesian Journal of Pharmacy, 18(3), I54-161.

Meiyanto, E., 1996, Efek Antimutagenik Beberapa Fraksi Ekstrak Alkohol Daun Gynura procumbens (Lour)Merr, Laporan Penelitian, Fakultas Farmasi UGM, Yogyakarta. 
Meiyanto, E., Tasminatun, S., Susilowati, S., Murwanti, R. and Sugiyanto, 2007b, Penghambatan Karsinogenesis Kanker Payudara Tikus terinduksi DMBA pada fase Post Inisiasi oleh ekstrak etanolik Gynura procumbens (Lour) Merr., Majalah Farmasi Indonesia., I 8(4), I54-I6I.

Newall, C.A., Anderson, L.A. and Phillipson, J.D., Herbal Medicines. A Guide for Health-care Professionals; Pharmaceutical Press: London, UK, 1996.

Rosidah, Yam. M.F., Sadikun, A. and Asmawi M.Z., 2008, Antioxidant potential of Gynura procumbens, Pharmaceutical Biol., 46, 616625.

Schulz, V., Rudolf, H. and Tyler, V.E., 1998, Rational Phytotherapy. A Physician's Guide to Herbal Medicine, 3rd ed., Springer, Berlin, Germany.

Sugiyanto, Sudarto, Meiyanto, E., Nugroho, A.E. and Jenie, U.A., 2003, The anticarcinogenic activity of plants compounds, Indonesian Journal of Pharmacy, I 4(4), 21 6-225.

WHO, 2006, Cancer Control, Knowlendge into Action, WHO Guide for Effective Programes, www.who.int/cancer. 